\title{
Conservative treatment of juvenile with Chiari I malformation, syringomyelia and scoliosis. Two case reports
}

\author{
M Rigo $^{1 *}$, B Janssen ${ }^{2}$, R Campo ${ }^{2}$, L Tremonti $^{2}$ \\ From 9th International Conference on Conservative Management of Spinal Deformities - SOSORT 2012 \\ Annual Meeting \\ Milan, Italy. 10-12 May 2012
}

\section{Background}

Scoliosis improvement after surgical treatment of Chiari I and syrinx has been reported [1]. Incidence of scoliosis progression after decompression surgery has been reported as high as $48 \%$. The conservative treatment with brace in these patients is not effective and scoliosis is typically progressive [2]. Spontaneous resolution of CT syrinx and Chiari I in paediatric population is uncommon. We have previously published a unique case report of an 8-year-old girl, showing resolution of syrinx and Chiari I, as well as scoliosis reduction of scoliosis during brace treatment [3]. We present results after longer follow up, together with a new case of good response to bracing, in a girl showing scoliosis progression after neurosurgical treatment.

\section{Case Presentation}

\section{First case presentation}

A 7-year-old girl who showed scoliosis progression from $44^{\circ}$ to $55^{\circ}$ six months after neurosurgical decompression to treat Chiari I (10-11 mm tonsillar ectopia) associated with C5-T11 syrinx was subsequently recommend going under scoliosis surgery (rejected). Eight months following neurosurgery, patient began full-time treatment with a Chêneau type brace (RSC). She started later a program of specific exercises based on Schroth-Barcelona (BSPTS). At 12 years of age ( 5 years follow-up) she shows a $6^{\circ}$ main thoracic curve in her 4th brace, although still at Risser 0 . Formetric reports a totally regressed back asymmetry and physiological sagittal profile. The patient is

Institut Elena Salvá, Barcelona, Spain

Full list of author information is available at the end of the article asymptomatic and continues full time bracing and exercises.

\section{Second case presentation}

A 13-year-old girl started full time bracing when she was 8 years old, after showing progression from $36^{\circ}$ to $47^{\circ}$ in five months in her right thoracic scoliosis associated with symptomatic Chiari I and C4-T9-10 syrinx. She showed spontaneous resolution of Chiari I and almost resolution of syrinx with no recurrence, and good response to bracing. At five years follow-up she continues partial-time bracing $(16 \mathrm{H})$ and BSPTS exercises, asymptomatic, with a main thoracic curve of $17^{\circ}$ (combined with $17^{\circ}$ functional left lumbar), one-year post-menarche and Risser 3. Back asymmetry is totally regressed and sagittal profile physiologic.

\section{Conclusion}

Conservative treatment should be considered in patients with Chiari I/syrinx associated to progressive scoliosis, prior to or post-neurosurgical intervention, and prior to scoliosis surgery.

\section{Author details \\ 'Institut Elena Salvá, Barcelona, Spain. 'SColiosisRehab, Stevens-Point, \\ Wisconsin, USA.}

Published: 3 June 2013

\section{References}

1. Mollano AV, Weinstein SL, Menezes AH: Significant scoliosis regression following syringomyelia decompression: case report. lowa Orthop J 2005, 25:57-59.

2. Colombo LF, Motta F: Consensus conference on Chiari: a malformation or an anomaly? Scoliosis and others orthopaedic deformities related to Chiari 1 malformation. Neurol Sci 32(Suppl 3):S341-343. 
3. LM RMaM: Spontaneous resolution of a Chiari malformation and cervicothoracic syrinx in a 9 years old girl with a $47^{\circ}$ scoliosis responding favorably to bracing. scoliosis 2009, 4(suppl 1):0-58.

doi:10.1186/1748-7161-8-S1-052

Cite this article as: Rigo et al:: Conservative treatment of juvenile with Chiari I malformation, syringomyelia and scoliosis. Two case reports. Scoliosis 2013 8(Suppl 1):052.

Submit your next manuscript to BioMed Central and take full advantage of:

- Convenient online submission

- Thorough peer review

- No space constraints or color figure charges

- Immediate publication on acceptance

- Inclusion in PubMed, CAS, Scopus and Google Scholar

- Research which is freely available for redistribution

Submit your manuscript at www.biomedcentral.com/submit
C Biomed Central 